\title{
OCCURRENCE AND FINANCIAL EFFECT OF OVINE AND BOVINE LIVER CONDEMNATIONS DUE TO ABSCESSES AND NECROSIS IN THE SUDAN
}

\author{
HIND OSMAN E ${ }^{1}$; ELSIR, B. ${ }^{2}$ and MOHAMED T. EBRAHIM ${ }^{3}$. \\ ${ }^{1}$ Sudan University of Science and Technology, Faculty of Veterinary Medicine. \\ ${ }^{2}$ and ${ }^{3}$ Sudan University of Science and Technology, Faculty of Animal Production. \\ Email: 1. hindosman@sustech.edu 2.hmmhmm12345@yahoo.com
}

\section{ABSTRACT}

Received at: $24 / 10 / 2013$

Livers are known to be of high nutritional value. They are eaten raw as a food habit in the Sudan. Surveys regarding liver abscesses and necrosis in ovine and bovine livers were carried out to reflect their magnitude as liver affections and their economic effect. Retrospective studies of liver condemnation of slaughtered animals in Omdurman Central Abattoir were carried out at different periods during 1994 and 1995 and for the whole seven years from 1996 to 2002 in Elsabalouga Abattoir. Monthly records in the latter years were used to study the effect of season on liver condemnation. Liver condemnations due to different affections in slaughtered sheep and cattle during the period 1994-1995 were found to be $26.2 \%$ and $5.4 \%$ respectively. Out of those condemnations $57.6 \%$ and $22 \%$ respectively were found to be due to abscesses and necrosis. The surveillance of the liver condemnation in Elsabalouga Abattoir, during the period 1996-2002, revealed $77.43 \%$ condemned livers due to abscesses and necrosis out of the total condemned livers that in turn constituted $15.45 \%$ of the examined ovine livers. Out of $10.69 \%$ of the bovine condemned livers due to different affections, $11.96 \%$ were condemned due to abscesses and necrosis. There was strong to moderate correlation between the total condemned ovine and bovine livers and the condemnation due to abscesses and necrosis. Seasons were found to be of no significant effect on the ovine and bovine liver condemnations.

Key words: Ovine, Bovine, Liver condemnations, Abscesses.

\section{INTRODUCTION}

Liver condemnations constitute a high economic loss. Liver of small ruminants was reported to be the most condemned organ in a survey made in Ethiopia (Regassa, 2013). While in Tenzania liver was reported to be one of the two most frequently condemned organs in food animals including sheep and cattle (Mellau et al. 2011). In previous studies, condemnation due to abscesses and necrosis was shown to be of statistical significance (Jensen et al., 1954.) The percentage of these liver affections was studied in several countries (Anon 1960, 1961, 1962; Hussien, 1973; Jensen, 1974, Kanoe et al., 1979; Khatzmnol and Koskoal, 1991); it was shown to be steadily increasing in some of them (Newson, 1938; Kanoe et al., 1976). The percentage of bovine liver condemnation in a study made in Ethiopia, in 2011 2012 , was found to be $66.06 \%$ with $4.09 \%$ condemned livers due to abscesses (Hailemariam, 2012). Ovine liver condemnation was surveyed in an Ethiopian abattoir and found to constitute $87.72 \%$ of which $3 \%$ was due to abscessation (Getachew, 2007).

\section{OBJECTIVES}

The livers of slaughtered cattle and sheep in Omdurman Central Abattoir and Elsabalouga Abattoir were surveyed during 1994-2002, for presence of lesions in general and for abscesses and necrosis in specific, to study these affections and to estimate their economic impact in Sudan.

\section{Methods}

To attend the meat inspection of sheep and cattle slaughtered for exportation and for the three townsKhartoum, Khartoum North, and Omdurman, regular visits for Omdurman Central Abattoir and Elsabalouga Abattoir were carried out. The animals slaughtered have originated from several localities in the Sudan. Liver condemnation in 3522 slaughtered lambs and 2376 slaughtered heavy bulls was actively surveyed in Omdurman Central Abattoir over a period of six months during 1994 and 1995. A second survey was carried out over a period of three months from January to March in 2002 in Elsabalouga Abattoir, liver 
condemnation in 14717 slaughtered lambs and 795 slaughtered heavy bulls was actively surveyed.

Livers were examined grossly and the ones contained abscesses and necrosis were sorted out, collected in plastic bags and taken to the laboratories of Faculty of veterinary medicine, University of Khartoum or of Faculty of veterinary medicine Sudan University of Science and Technology. Samples of $1 \times 1 \mathrm{~cm}$ were fixed in $10 \%$ formal saline and processed as described by Drury and Walungtone (1980). Microscopic examination for the histologically processed tissue sections was carried out to confirm the type of lesion.

Retrospective studies of liver condemnation were carried out at different periods during 1994 and 1995 depending on the availability of the records in Omdurman Central Abattoir; and for the whole seven years from 1996 to 2002 in Elsabalouga Abattoir. Monthly records in the latter years were used to study the effect of season on liver condemnation.

To study the economic impact of ovine and bovine liver condemnation, fifty ovine and fifty bovine carcasses and livers were weighed; and survey was carried out for the prices of the carcass and liver of the two food animals in the three towns.

\section{RESULTS}

The results have shown that abscesses in bovine and ovine livers varied in sizes from 0.5 to $7 \mathrm{~cm}$ in diameter. They were pallor in color than the surrounding apparently normal liver tissue, elevated from the surface, mostly well circumscribed and occasionally superficially covered by obvious fibrous tissue.

The necrotic foci were pale yellow to grayish white of 0.1 to $0.5 \mathrm{~cm}$ in diameter. The lesions were firm and vary greatly in shape.

In Omdurman Abattoir, 922 (26.2\%) out of 3522 inspected sheep livers, were condemned due to different affections. Necrosis and abscesses were observed in $531(57.6 \%)$ of the condemned livers. In 2476 inspected cattle livers, $129(5.4 \%)$ liver were condemned due to different affections. 29 (22\%) of the total condemned livers were condemned due to abscesses and necrosis (table. 1).

The surveillance of the liver condemnation in Elsabalouga Abattoir revealed that 2273 (15.45\%) out of 14717 inspected ovine livers were condemned due to different affections. Necrosis and abscesses were observed in $1760(77.43 \%)$ of the condemned livers. Out of 795 inspected bovine livers in the same abattoir, 85(10.69\%) liver were condemned due to different affections. Necrosis and abscesses were observed in $10(11.96 \%)$ of the condemned livers (table. 1).

Ovine and bovine liver condemnation that have appeared in the earlier annual reports of Omdurman Central Abattoir during different periods in 1994-1995 are shown in Figure (1) and Figure (2) respectively. Frequencies and percentages of ovine and bovine liver condemnations in Elsabalouga Abattoir from 1996 to 2002 are shown in Table (2) and Table (3) respectively.

The correlation between slaughtered animals and liver condemnation in ovine and bovine is shown in table (4) and table (5), respectively. There was strong positive and moderate correlation between the total condemned ovine livers and the condemnation due to necrosis and abscesses, respectively and a strong positive correlation between the total condemned bovine livers and condemnation due to necrosis and abscesses each.

Liver was found to constitute $2.43 \%$ of the bovine carcass weight and $3.13 \%$ of the ovine carcass weight. The price of ovine liver was found to be 25 Sudanese Pounds and the price of the bovine liver was found to be about 60 Sudanese Pound/ Kg. The price is approximately the same in the three towns: Khartoum, Khartoum North and Omdurman. The average annual losses due to liver condemnation during 1994-1995 in ovine 2.063.700 Sudanese Pounds and the losses due to liver abscess and necrosis constitutes about 1038078.5 Sudanese Pounds In bovine the total condemned livers costs about 12603600 Sudanese Pounds and that due to abscessed and necrotic liver condemnation is 359691.78 Sudanese Pounds. The average annual losses due to total ovine liver condemnations in 1996-2002 was found to be 1681785.8 Sudanese Pounds and the losses due to liver abscess and necrosis constituted about 88967.75 Sudanese Pounds.

In bovine the average annual losses due to total ovine liver condemnations in 1996-2002 was found to be 1405895.7 Sudanese Pounds and the losses due to liver abscess and necrosis constituted about 387090 Sudanese Pounds.

The effect of season on the liver condemnation was studied in the three seasons: dry summer, wet summer and winter over seven years from 1996 to 2002. It revealed no significant effect on both ovine and bovine liver condemnations. The number of slaughtered animals and liver condemnation was found to be the least in the dry summer.

Table 1: Condemned ovine livers in relation to slaughtered animals actively surveyed in Elsabalouga Abattoir 
Assiut Vet. Med. J. Vol. 60 No. 140 January 2014

and Omdurman Central Abattoir.

\begin{tabular}{ccccc}
\hline Slaughtered animals & Abattoir & TSA & TC & AN \\
\hline Ovine & Elsabalouga & 14717 & 2273 & 1760 \\
& & & $(15.45 \%)$ & $(77.43 \%)$ \\
\cline { 2 - 5 } & Omdurman & 3522 & 922 & 531 \\
& & & $(26.2 \%)$ & $(57.6 \%)$ \\
\hline \multirow{2}{*}{ Bovine } & Elsabalouga & 795 & 85 & 10 \\
& & & $(10.69 \%)$ & $(11.96 \%)$ \\
\cline { 2 - 5 } & Omdurman & 2476 & 129 & 29 \\
& & & $(5.4 \%)$ & $(22 \%)$ \\
\hline
\end{tabular}

$\mathrm{TSA}=$ Total slaughtered animals $; \mathrm{TC}=$ Total liver condemnations; $\mathrm{AN}=$ Liver condemnation due to abscesses and necrosis.

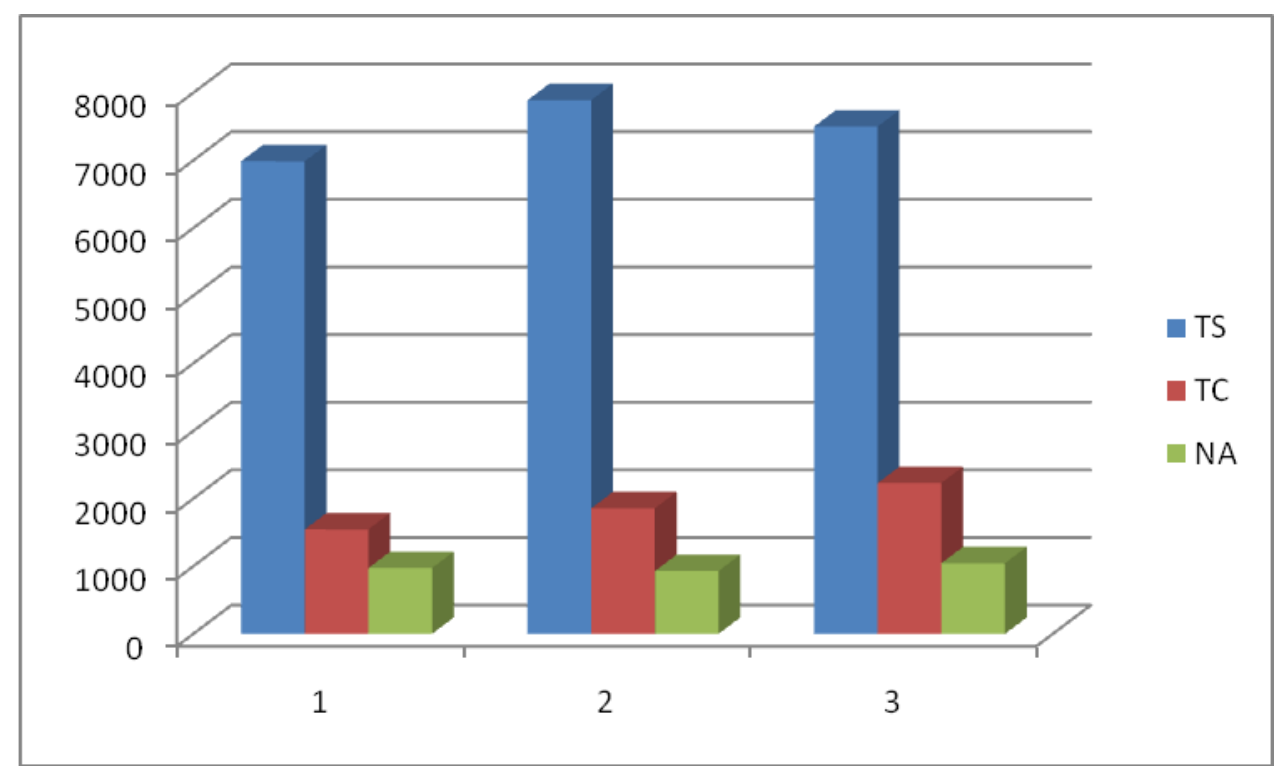

$\mathrm{TS}=$ Total slaughtered animals; $\mathrm{TC}=$ Total condemned livers; NA= condemned livers due to abscesses and necrosis.

Fig. 1 Condemned ovine livers in relation to slaughtered animals in Omdurman Central Abattoir during three different periods in 1994-1995. 


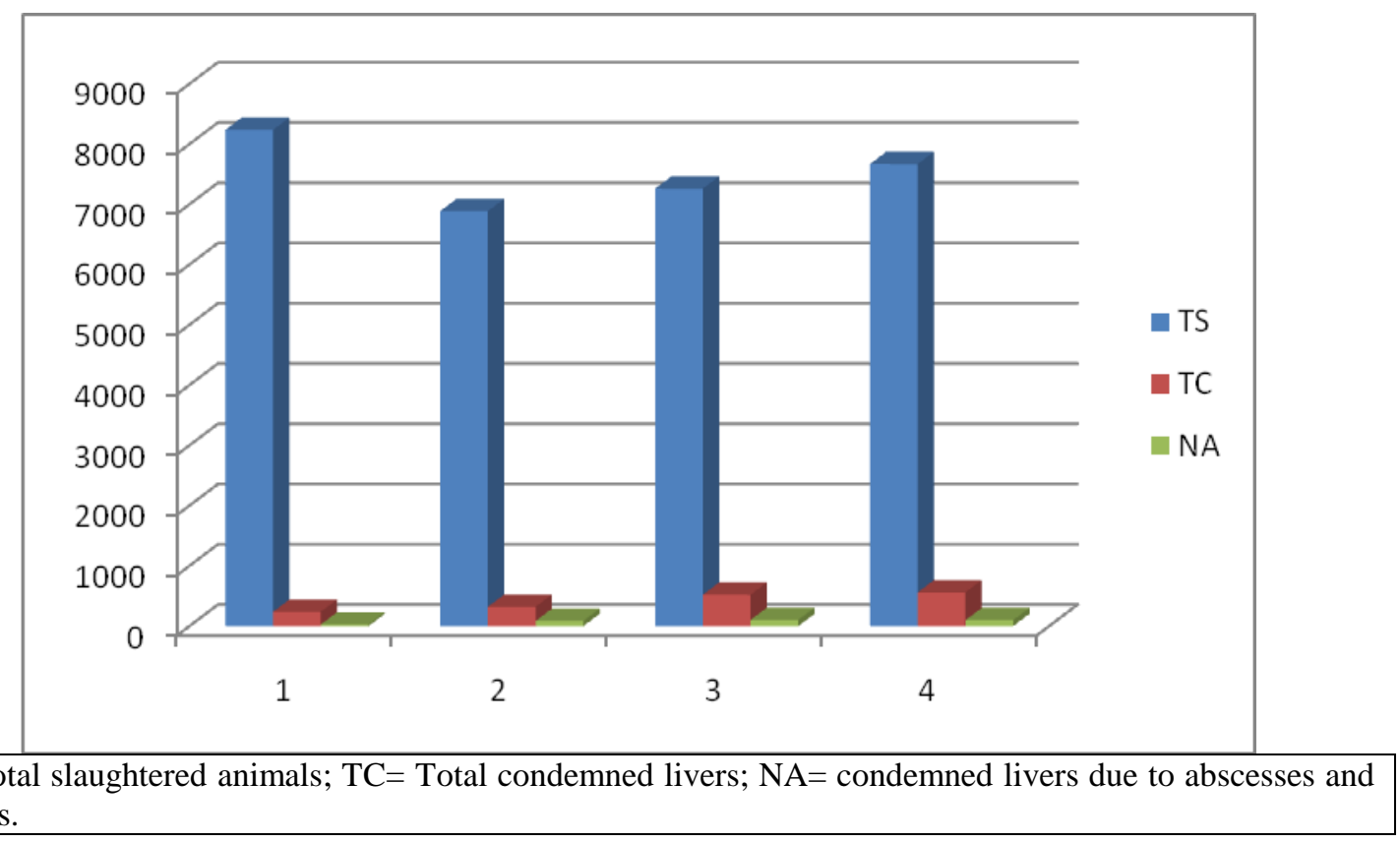

Fig. 2: Condemned bovine livers in relation to slaughtered animals in Omdurman Central Abattoir during four different periods in 1994-1995.

Table 2: Frequencies and percentages of total ovine liver condemnation and of condemnation due to abscesses and necrosis in relation to slaughtered animals recorded in Elsabalouga Abattoir.

\begin{tabular}{cccc}
\hline & TSA & TC & AN \\
\hline 1996 & $272740(100 \%)$ & $92602(34.00 \%)$ & $60749(66.00 \%)$ \\
\hline 1997 & $3728388(100 \%)$ & $121705(3.26 \%)$ & $69035(57.00 \%)$ \\
\hline 1998 & $672342(100 \%)$ & $151960(22.6 \%)$ & $69404(45.67 \%)$ \\
\hline 1999 & $5062726(100 \%)$ & $63133(1.25 \%)$ & $28925(45.82 \%)$ \\
\hline 2000 & $1055708(100 \%)$ & $30618(2.9 \%)$ & $19180(62.64 \%)$ \\
\hline 2001 & $87155(100 \%)$ & $4233(4.86 \%)$ & $1738(41.06 \%)$ \\
\hline 2002 & $230695(100 \%)$ & $6649(2.88 \%)$ & $41(.062 \%)$ \\
\hline
\end{tabular}

TSA = Total slaughtered lambs; $\mathrm{TC}=$ Total ovine liver condemnations; $\mathrm{AN}=$ Condemnation of ovine livers due to abscesses and necrosis;

Table 3: Frequencies and percentages of total bovine liver condemnation and of condemnation due to abscesses and necrosis in relation to slaughtered animals recorded in Elsabalouga Abattoir.

\begin{tabular}{cccc}
\hline & TSA & TC & AN \\
\hline 1996 & $80215(100 \%)$ & $5580(6.96 \%)$ & $1872(33.55 \%)$ \\
\hline 1997 & $77846(100 \%)$ & $7354(9.45 \%)$ & $2178(29.62 \%)$ \\
\hline 1998 & $109369(100 \%)$ & $7149(6.54 \%)$ & $1841(25.75 \%)$ \\
\hline 1999 & $53890(100 \%)$ & $3946(7.32 \%)$ & $1251(31.7 \%)$ \\
\hline 2000 & $45055(100 \%)$ & $3049(6.77 \%)$ & $777(25.48 \%)$ \\
\hline 2001 & $29488(100 \%)$ & $2211(7.50 \%)$ & $278(12.57 \%)$ \\
\hline 2002 & $13786(100 \%)$ & $533(3.87 \%)$ & $14(2.63 \%)$ \\
\hline
\end{tabular}

TSA = Total slaughtered bulls; $\mathrm{TC}=$ Total bovine liver condemnations; $\mathrm{AN}=$ Condemnation of bovine livers due to abscesses and necrosis; 
Table 4: Correlation between slaughtered sheep and condemned livers in Elsabalouga Abattoir from 1996 to 2002.

\begin{tabular}{|c|c|c|c|c|c|}
\hline & \multicolumn{5}{|c|}{ Correlations } \\
\hline & & $\mathrm{TC}$ & $\mathrm{AN}$ & $\mathrm{N}$ & A \\
\hline \multirow{3}{*}{ TSA } & Pearson Correlation & 0.275 & 0.253 & 0.214 & 0.392 \\
\hline & Sig. (2-tailed) & 0.551 & 0.584 & 0.645 & 0.384 \\
\hline & $\mathrm{N}$ & 7 & 7 & 7 & 7 \\
\hline \multirow{3}{*}{$\mathrm{TC}$} & Pearson Correlation & & $.971 * *$ & $.951 * *$ & $.798^{*}$ \\
\hline & Sig. (2-tailed) & & 0 & 0.001 & 0.031 \\
\hline & $\mathrm{N}$ & & 7 & 7 & 7 \\
\hline
\end{tabular}

TSA = Total slaughtered lambs $; \mathrm{TC}=$ Total ovine liver condemnations $; \mathrm{AN}=$ Condemnation of ovine livers due to abscesses and necrosis; $\mathrm{N}=$ Condemnation of ovine livers due to necrosis; $\mathrm{A}=$ Condemnation of ovine livers due to abscesses $* *$. Correlation is significant at the 0.01 level (2-tailed).

*. Correlation is significant at the 0.05 level (2-tailed).

Table 5: Correlation between slaughtered cattle and condemned livers in Elsabalouga Abattoir from 1996 to 2002.

\begin{tabular}{|c|c|c|c|c|c|}
\hline \multicolumn{6}{|c|}{ Correlations } \\
\hline & & $\mathrm{TC}$ & $\mathrm{AN}$ & A & $\mathrm{N}$ \\
\hline \multirow{3}{*}{$\mathrm{TS}$} & Pearson Correlation & $.950 * *$ & $.912 * *$ & $.884 * *$ & $.894 * *$ \\
\hline & Sig. (2-tailed) & 0.001 & 0.004 & 0.008 & 0.007 \\
\hline & $\mathrm{N}$ & 7 & 7 & 7 & 7 \\
\hline \multirow{3}{*}{$\mathrm{TC}$} & Pearson Correlation & & $.972 * *$ & $.932 * *$ & $.954 * *$ \\
\hline & Sig. (2-tailed) & & 0 & 0.002 & 0.001 \\
\hline & $\mathrm{N}$ & & 7 & 7 & 7 \\
\hline
\end{tabular}

TSA = Total slaughtered bulls; $\mathrm{TC}=$ Total bovine liver condemnations; $\mathrm{AN}=$ Condemnation of bovine livers due to abscesses and necrosis; $\mathrm{N}=$ Condemnation of bovine livers due to necrosis; $\mathrm{A}=$ Condemnation of bovine livers due to abscesses

**. Correlation is significant at the 0.01 level (2-tailed).

*. Correlation is significant at the 0.05 level (2-tailed).

\section{DISCUSSION}

A prerequisite to a proper meat industry is the recognition of the disease conditions that affect the quality and safety of meat. This is usually met by strict meat hygiene in the process of meat inspection of parts, organs and entire carcasses.

Liver inspection and condemnation has a socioeconomic impact in the Sudan. Consumption of raw liver is a food habit in the whole country that increases the risk at consumption of the diseased ones.
The total ovine liver condemnation were studied before by Hussein (1973) who gave a range of 7.3 to $9.3 \%$ over a period of three consecutive years. The average of these percentages decreased from $8.6 \%$ to $7.3 \%$ in the first two years and increased during third year to $9.3 \%$. Comparing the findings observed in the current study with those in Hussein (1973), the percentage of liver condemnation during 1994 to end of 1995 was increased about three folds to be 20 to $27 \%$. In the last seven years, 1996-2002 the percentage of total ovine liver condemnation ranges from $34 \%$ to $1.25 \%$ with a decreasing tendency 
towards 2002. The results of the current study and the previous one show a considerable fluctuation in the number of the condemned ovine livers from 1973 to 2003. But the percentage of condemnation due to abscesses and necrosis shows an increment in19941995 study which was $57.6 \%$ and in 1996-2002 which was $77.43 \%$. This may be due to the improvement in sheep fattening program in those years as reflection of the improved veterinary extension. The relationship between animal fattening and these liver affections was stated before by Jensen and Donald (1965).

As indicated by Hussein (1973) liver condemnation in bovine was fluctuating from one year to another with an average of $14.55 \%$. In 1994-1995 the percentage of the liver condemnation was less than the half of that percentage in Hussein study (1973) whereas the percentages of bovine liver condemnation over the period from 1996 to 2002 were higher than that of 1994-1995 percentage and less that that of Hussein (1973). When actively surveyed, bovine liver condemnation due to abscesses and necrosis ranged from 3.4to $3.5 \%$ in 1973 study (Hussein, 1973), 1.2 $\%$ in 1994-1995 and 0.013 in 2003. That decrease could be attributed to the improved animal husbandry and veterinary care.

The percentage of bovine liver condemnation due to abscesses and necrosis was found to range from $33.55 \%$ to $2.63 \%$. Higher rates of liver condemnation due to abscesses and necrosis in the retrospective studies may indicate error in reporting the causes of condemnation or reflects the difference in the periods of collected data which is short in the active survey compared to the retrospective study using the records.

Compared to neighboring countries, the percentages of ovine liver condemnation in Sudan show lower rates; in Ethiopia it constituted $87.72 \%$ (Getachew, 2007). The difference in bovine liver condemnation between Sudan and Ethiopia is much pronounced than that of sheep, however, it also shows a lower rate compared to that in Ethiopia which was found to be $66.06 \%$.

In spite of the variation in the numbers of slaughtered animals and the ovine and bovine liver condemnations in the three seasons: dry summer, wet summer and winter, the effect of season on total liver condemnations and liver condemnations due to abscesses and necrosis was found to be insignificant. The increases of numbers of slaughtered animals and condemned livers in winter and wet summer may be due to the effect of the feeding system in the Sudan. Effect of the year months on bovine liver abscessation was also reported by Harman et al. (1989).

It is worth mentioning that liver is known to be an important preferred edible type of meat in the Sudan. The monetary value of each of the condemned livers of sheep was 25 Sudanese pounds. It constituted about $3.5 \%$ of the total value of the animal in 1995 (Hind et al., 2002). Recently this percentage have been decreased greatly this may be due to the increased cost of food animals in general and/or decreased price of the preferred types of meat as a matter of supply and demand. The same percentage applies to the losses of the bovine livers whereas the effect is less on their price. This may be due to the fact that sheep livers are more preferred so they have much higher prices in1995. The annual ovine liver condemnations in the Sudan costs a value of about 800 lamb besides, there is loss of a highly nutritious type of food.

\section{REFERENCES}

Anon (1960, 1961 and 1962): Summary of Activities of Meat Inspection Division. Agricultural research service, U.S.D.A. ARS. 93: 456. Cited by Jensen, R. and Donald, R.M. (1965). q.v.

Druray, R.A.B. and Walungtone, E.A. (1980): Carlton's Histological Technique" $5^{\text {th }}$ Ed. Oxford Univ. Press.: New York.

Getachew, E.W. (2007): Major diseases of export oriented livestock in export abattoirs in /around Ada Liben Wereda, Debre Zeit. A thesis submitted in partial fulfillment for the attainment of the degree, Doctor of Veterinary Medicine to the Faculty of Veterinary Medicine, Haramaya University, Ethiopia.

Hailemariam, Z.; Mohammed, N. and Mindaye, S. (2012): Major causes of liver condemnation and associated financial loss at Kombolcha abattoir, Soutyh Wollow. Ethiopia. Europian Journal of Applied Science4 (4): 140-145.

Harman, B.R.; Brinkman, M.H.; Hoffman, M.P. and Self, H.L. (1989): Factors affecting in-transit shrink and liver abscesses in fed steers. J. Anim. Sci. 67: 311-317.

Hind Osman, E.; Idris, U.A.; Sary Eldin, M. and ElSanosi, S.M. (2002): Condemnation of ovine and bovine livers due to abscesses and necrotic lesions in the Sudan. 27th Veterinary Mondial (World Veterinary Association) 2002, Tunisia.

Hussein, E.H. (1973): A bacteriologic study of liver abscesses in cattle and sheep in the Sudan. M. Sc. Thesis. Khartoum: Khartoum University.

Jensen, R. (1974): "Diseases of Sheep". Philadelphia: Lea and Febiger.

Jensen, R. and Donald, R. (1965): "Disease of feed lot cattle". Philadelphia: Lea and Febiger

Jensen R.; Cooper, L.J.; Harold, M.D.; Victora, M. and Graham, W.R. (1954): The ruminitis liver abscess complex in beef cattle. Am. J. Vet. Res. 15: 5-14.

Kanoe, M.; Imagua, H.; Toda, M.; Sato, A. and Inoue, M. (1976): Bacteriology of bovine hepatic abscesses. Jpn. J. Vet. Sci. 38: 263-268.

Kanoe, M.; Izugi, Y.; Kimi, M.; Toda, M. and Hara, Y. (1979): Hepaticabscesses in fattened diary 
steers. . Jpn. J. Vet. Sci. 41: 73-76.

Khatzmol, A. and Koskols, 1. (1991): Frequency and causes of the syndrome of ruminits and liver abscess in calves fattened intensively in Greece. Deltion tes Eilenikes kteniatrikes Etaireias 42: 175-179.

Mellau, B.L.; Nonga, H.E. and Karimuribo, E.D. (2011): Slaughter stock abattoir survey of carcasses and organ/offal condemnation in Arusha region, northern Tenzania. Trop Anim
Health Prod 43 (4): 857-64.

Newsom, I.E. (1938): A bacteriologic study of liver abscesses in cattle. J. Infect. Dis. 63: 132-237.

Regassa, A.; Moje, N.; Megersa, B.; Beyene, D.; Sheferaw, D.; Debela, E.; Abunna, F. and Skjerve, E. (2013): Major causes of organs and carcass condemnation in small ruminants slaughtered at Luna Export Abattoir, Oromia Regional State, Ethiopia. Prev Vet Med. 110 (2): 139-148.

\title{
التواجد والأثر الإقتصادى لإعدامات أكباد الضأن والأبقار نتيجة للإصابة بالنخر والخراج فى السودان \\ هند الريح عثمان ، بهاء السر ، محمد تاج الدين ابراهير
}

Email: hmmhmm12345@yahoo.com, hindosman@ sustech.edu

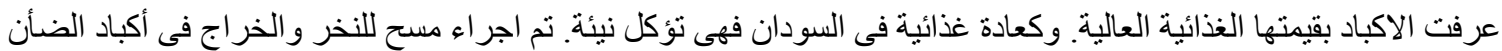

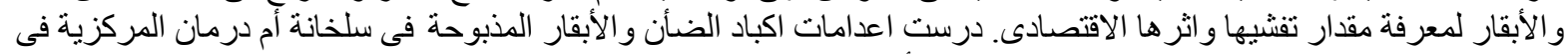

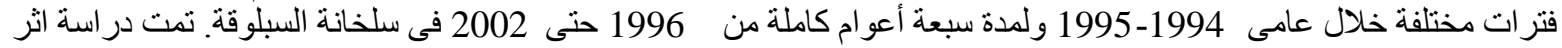

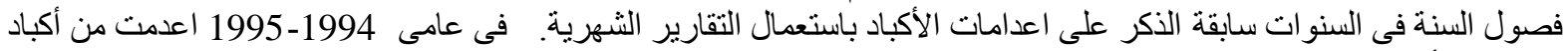

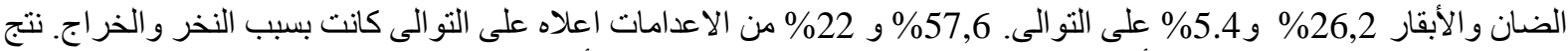

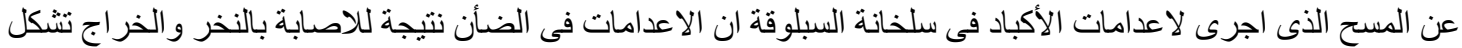

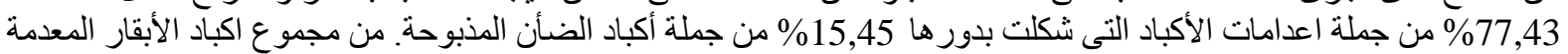

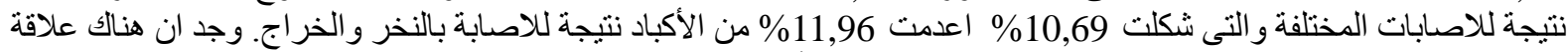

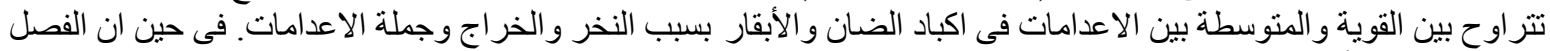
السنوى ليس ذو أثر ملحوظ على هذه الاعدامات.
\end{abstract}

